\title{
KERAGAAN PERTUMBUHAN TANAMAN JARAK PAGAR (JATROPHA CURCASS) DI PEMBIBITAN AKIBAT PEMBERIAN MIKORIZA DI DUA LOKASI BERBEDA BERDASARKAN KETINGGIAN TEMPAT
}

\section{DIVERSITY OF JATROPHA CURCASS PLANT IN SEEDING DUE TO GIVING MYCORRHIZA IN TWO DIFFERENT LOCATIONS BASED ON HEIGHT PLACE}

\author{
R A Hadi'ia \\ ${ }_{1}^{1}$ Program Studi Agroteknologi, Fakultas Pertanian, Universitas Winaya Mukti, Sumedang \\ a Korespondensi: Roni Assafaat Hadi, E-mail: roni.assafaat.hadi@gmail.com \\ (Diterima: 22-12-2018; Ditelaah:24 -12-2018; Disetujui: 05-01-2019)
}

\begin{abstract}
This study examines the growth performance of jatropha curcass in nurseries due to mycorrhizal administration in two different locations based on site height for the three IP-3P, IP-3A, IP-3M cultivars. Based on these objectives, the nature of this research is verification carried out by an experimental approach in the laboratory and in the field.The study was carried out in greenhouses, laboratories and fields in two locations based on the height of the Cirebon lowlands (0-50 masl) and medium terrain Jatinangor (850 masl) Pasir Banteng Seed Hall, with altitude $850 \mathrm{~m}$ above sea level. The experiment used a Randomized Block Design (RBD), which consisted of one combination factor, namely three levels of Jatropha cultivar type and five doses of the FMA consortium. Each treatment was repeated 3 times, then the total number: $3 \times 5 \times 3=45$ plots. The results of this study showed the growth performance of jatropha curcass in nurseries for the three IP-3P, IP-3A, IP-3M jatropha cultivars due to the administration of mycorrhizae in two different locations based on site height, ie 10 grams of the FMA dose consortium yielded results the best for mycorrhizal colonization, root biomass and FMA, and plant height.
\end{abstract}

Keywords: Cultivar, jatropha curcas, mycorrhiza.

\begin{abstract}
ABSTRAK
Penelitian ini mengkaji keragaan pertumbuhan tanaman jarak pagar (Jatropha curcass) di pembibitan akibat pemberian mikoriza di dua lokasi berbeda berdasarkan ketinggian tempat untuk ketiga kultivar IP-3P, IP-3A, IP-3M. Berdasarkan tujuan tersebut maka sifat dari penelitian ini adalah verifikatif dilakukan dengan pendekatan eksperimen di laboratorium dan di lapangan. Penelitian dilaksanakan di rumah kaca, laboratorium dan lapangan di dua lokasi berdaarkan ketinggian tempatnya dataran rendah Cirebon (0-50 mdpl) dan dataran medium Jatinangor (850 mdpl) Balai Benih Pasir Banteng, dengan ketinggian tempat $850 \mathrm{~m}$ dpl. Eksperimen menggunakan Rancangan Acak Kelompok (RAK), yang terdiri dari satu faktor kombinasi yaitu tiga taraf jenis kultivar jarak pagar dan lima taraf dosis konsorsium FMA. Tiap perlakuan diulang sebanyak 3 kali, maka jumlah keseluruhan : 3 × 5 × $3=45$ plot. Hasil penelitian tersebut menunjukkan keragaan pertumbuhan tanaman jarak pagar (Jatropha curcass) di pembibitan untuk ketiga kultivar jarak pagar IP-3P, IP-3A, IP-3M akibat pemberian mikoriza di dua lokasi berbeda berdasarkan ketinggian tempat yaitu dosis FMA konsorsium sebanyak 10 gram memberikan hasil yang terbaik untuk kolonisasi mikoriza, biomassa akar dan FMA, serta tinggi tanaman.
\end{abstract}

Kata kunci: Jarak pagar, mikoriza, kultivar. 
Hadi, R. A. (2019). Keragaan Pertumbuhan Tanaman Jarak Pagar (Jatropha curcass) Di Pembibitan Akibat Penberian Mikoriza Di Dua Lokasi Berbeda Berdasarkan Ketinggian Tempat. Jurnal Pertanian, 10(1), 43-51.

\section{PENDAHULUAN}

Salah satu sumber minyak nabati yang sangat prospektif untuk dimanfaatkan sebagai bahan baku biodiesel adalah biji jarak pagar (Jatropha curcas Linn.). Secara umum biji jarak tersusun atas kulit (shell) dan isi biji (cernel) yang di dalamnya terdapat embrio. Kulit menempati sekitar $28.82 \%$ dari biji, dan isi sekitar $71.19 \%$. Inti biji (cernel) jarak pagar mengandung sekitar $50 \%$ minyak sehingga dapat diekstrak menjadi minyak jarak dengan cara mekanis ataupun ekstraksi dengan pelarut seperti heksana. Minyak jarak pagar merupakan jenis minyak yang memiliki komposisi trigliserida yang mirip dengan minyak kacang tanah. Berbeda dengan sejenisnya jarak kaliki (Ricinus communis), dimana kandungan asam lemak esensial dalam kandungan minyak jarak pagar cukup tinggi sehingga sebetulnya bisa dikonsumsi sebagai edible oil, asalkan zat racun yang berupa phorbol ester dan curcin dihilangkan (Erliza Hambali, dkk., 2007).

Pertumbuhan tanaman jarak dapat dikatakan cepat dan dapat menghasilkan biji setelah berumur kurang lebih 1-3 tahun, tergantung pada lingkungan tumbuhnya dan teknis perbanyakannya baik secara generative maupun vegetatif (Heller 1996). Pengembangan produksi biji harus didukung dengan pengadaan benih berkualitas yang telah diseleksi, dengan harapan dapat mencapai potensi produksi yang sebenarnya. Dalam rangka pemenuhan bibit tanaman jarak yang berkualitas, perlu diperhatikan dua faktor penting didalam penyediaan benihnya khususnya untuk bahan penanaman di persemaian yaitu kualitas dan kuantitas benih. Pengadaan benih yang memiliki genetis yang baik dan tepat waktu merupakan faktor utama dalam keberhasilan pembibitan (Prihastanti, 2010). Pada tanaman jarak pagar, pembibitan dapat dilakukan secara langsung maupun tidak langsung (Henning, 2000 ; Prajapati dan Prajapati, 2005) dan pembibitan dengan cara perbanyakan generatif dari biji dilakukan hingga berumur 2-3 bulan (Heller, 1996; Henning, 1998; Henning, 2000).

Sebagai tanaman tahunan yang menghasilkan biji dan dapat hidup hingga lebih dari 50 tahun, tanaman jarak pagar sangat sensitive terhadap perubahan lingkungan termasuk iklim. Hal ini mengakibatkan produksinya berfluktuasi mengikuti perubahan lingkungan. Banyak kultivar jarak pagar yang ada di Indonesia dengan variasi keragaan pertumbuhan, hasil dan rendemen minyak. Hasil seleksi populasi terhadap kultivar jarak pagar yang dilakukan oleh Kebun Induk Jarak Pagar Pakuwon Kabupaten Sukabumi, pada tahun 2007 kebun induk Pakuwon telah melepaskan 1P-2P. Populasi IP-2P merupakan hasil seleksi dari IP-1P yang ditanam di Pakuwon Sukabumi. Kemudian pada tahun 2008 menghasilkan kultivar IP-3P (Improve Population 3 Pakuwon) yang merupakan hasil seleksi massa negatif (Mencabut dan membuang tanaman yang tidak diinginkan/tidak memenuhi kriteria dan mempertahankan tanaman yang diinginkan di pertanaman) dari IP-2P. Kelebihan dari IP-3P antara lain memiliki potensi produksi 2,3 - 2,5 ton/ha/tahun untuk tahun pertama. Dan bisa mencapai 8 s.d 9 ton/ha pada tahun ke empat. Hasil ini jauh melampaui potensi produksi IP-2P yang hanya sekitar 6,0 - 6,5 ton/ha pada tahun yang sama. Kadar minyak dari potensi IP-3P (Pakuwon) adalah sebesar 36 persen (Pusat Penelitiaan dan Pengembangan Perkebunan, 2009).

Setiap lahan dengan ketinggian topografi wilayah yang berbeda memiliki sifat kimiawi tanah yang berbeda, seperti tingkat tersedia unsur P dalam tanah, seperti Fungi Mikoriza Arbuskula (FMA) yaitu golongan mikroba yang membantu melepaskan P terikat menjadi P tersedia. FMA juga membantu tanaman untuk menyerap unsur hara terutama unsure hara fosfat (P). Fungi Mikoriza Arbuskula (FMA) dapat meningkatkan penyerapan air dan unsure hara, melindungi tanaman dari pathogen akar dan unsure toksik. FMA juga menghasilkan hormone yang berupa sitokinin yang membantu tanaman mengatur pertumbuhannya (Nuhamara, 1994; Varma, 2008). Selain itu, FMA Berperan dalam perbaikan struktur tanah, meningkatkan kelarutan hara dan proses pelapukan bahan induk. FMA mendapat keuntungan dari tanaman inang berupa senyawa karbon dari hasil fotosintesis. Hubungan yang terjadi antara FMA dan akar tanaman merupakan hubungan simbiosis mutualisme atau saling menguntungkan (Gonzalo dan Miguel, 2006). Fungi Mikoriza dapat memanfaatkan eksudat akar tumbuhan sebagai sumber karbon dan energi, 
sedangkan tumbuhan lebih mudah menyerap unsur hara, khususnya unsur hara P (Preston, 2007 dalam Cucu Suherman, 2011).

Jatinangor di Kabupaten Sumedang dengan ketinggian tempat sekitar $734 \mathrm{~m}$ di atas permukaan laut (dpl), mempunyai tipe curah hujan C begitu pun Sindanglaut di Kabupaten Cirebon dengan ketinggian tempat sekitar $50 \mathrm{~m}$ dpl, juga memiliki tipe curah hujan $\mathrm{C}$ menurut klasifikasi Schmidt dan Feguson, (1951). Di kedua tempat tersebut memiliki ordo tanah yang sama yaitu Inceptisol. Ketinggian tempat berbeda akan berbeda terhadap proses fisiologi tanaman. Perbedaan ini akan mempengaruhi pertumbuhan tanaman. Suatu kultivar yang sama apabila ditanam pada lingkungan yang berbeda maka pertumbuhan dan hasilnya akan berbeda terlebih jika berbeda kultivar. Kondisi lingkungan yang berbeda seperti iklim, suhu, intensitas cahaya matahari dan jenis tanah merupakan faktor pendukung dalam suatu budidaya tanaman (Rosniawaty S., $d k k ., 2008$ ).

\section{MATERI DAN METODE}

Penelitian ini mengkaji pengaruh untuk mendapatkan tingkat efektivitas aplikasi FMA (Fungi Mikoriza Arbuskula) dan pertumbuhan tanaman jarak pagar (Jatropha curcas Linn.), untuk ketiga kultivar IP-3P, IP-3A, IP-3M serta mempelajari peran enzim phosfate dan asam fosfat yang dihasilkan oleh FMA akibat bersimbiosis dengan tanaman jarak pagar ketiga kultivar IP-3P, 1P-3A, 1P-3M. Berdasarkan tujuan tersebut maka sifat dari penelitian ini adalah verifikatif dilakukan dengan pendekatan eksperimen di laboratorium dan di lapangan. Penelitian dilaksanakan di rumah kaca, laboratorium dan lapangan di dua lokasi berdaarkan ketinggian tempatnya dataran rendah Cirebon (0-50 mdpl) dan dataran medium Jatinangor (850 mdpl) kebun produksi Fakultas Pertanian Universitas Winaya Mukti Tanjungsari Sumedang, dengan ketinggian tempat $850 \mathrm{~m} \mathrm{dpl}$.

Eksperimen menggunakan Rancangan Acak Kelompok (RAK), yang terdiri dari satu faktor kombinasi yaitu tiga taraf jenis kultivar jarak pagar dan lima taraf dosis konsorsium FMA. Tiap perlakuan diulang sebanyak 3 kali, maka jumlah keseluruhan : 3 × 5 × $3=45$ plot. Respon perkecambahan dan pertumbuhan tanaman dalam rangka menguji hipotesis, dilakukan analisis varians (uji F) dengan model linier Rancangan Acak Kelompok (RAK). Rancangan percobaan yang digunakan adalah Rancangan Acak Kelompok (RAK) pola sederhana yang terdiri dari lima belas kombinasi perlakuan. Jumlah kombinasi perlakuan 15 yang diulang 2 kali, sehingga jumlah petak dalam percobaan ini ada 30. Penempatan perlakuan pada tiap ulangan dilakukan secara acak.

$\mathrm{A}=$ Kultivar IP-3P dengan aplikasi Konsorsium FMA 0 gr/polibag; $B=$ Kultivar IP-3A dengan aplikasi Konsorsium FMA 0 gr/polibag; $\mathrm{C}=$ Kultivar IP-3M dengan aplikasi Konsorsium FMA 0 gr/polibag; D = Kultivar IP-3P dengan aplikasi Konsorsium FMA 2,5 gr/polibag; E = Kultivar IP$3 \mathrm{~A}$ dengan aplikasi Konsorsium FMA 2,5 gr/polibag; $\mathrm{F}=$ Kultivar IP-3M dengan aplikasi Konsorsium FMA 2,5 gr/polibag; G = Kultivar IP3P dengan aplikasi Konsorsium FMA 5,0 gr/polibag; $\mathrm{H}=$ Kultivar IP-3A dengan aplikasi Konsorsium FMA 5,0 gr/polibag; I = Kultivar IP3M dengan aplikasi Konsorsium FMA 5,0 gr/polibag; J = Kultivar IP-3P dengan aplikasi Konsorsium FMA 7,5 gr/polibag; $\mathrm{K}=$ Kultivar IP$3 A$ dengan aplikasi Konsorsium FMA 7,5 gr/polibag; L = Kultivar IP-3M dengan aplikasi Konsorsium FMA 7,5 gr/polibag; M = Kultivar IP3P dengan aplikasi Konsorsium FMA 10,0 gr/polibag; N = Kultivar IP-3A dengan aplikasi Konsorsium FMA 10,0 gr/polibag; dan $0=$ Kultivar IP-3M dengan aplikasi Konsorsium FMA 10,0 gr/polibag.

Analisis hasil pengamatan diuji menggunakan metode statistik berdasarkan model linier Rancangan Acak Kelompok (RAK) pola sederhana sebagai berikut :

$\mathbf{X} \mathbf{i j}=\boldsymbol{\mu}+\mathbf{r}_{\mathbf{i}}+\mathbf{t}_{\mathbf{j}}+\mathbf{e}_{\mathbf{i j}}$

Berdasarkan model linier, maka disusun daftar sidik ragam seperti pada Tabel 1. 
Tabel 1. Daftar Sidik Ragam RAK Pola Sederhana

\begin{tabular}{lccccc}
\hline Sumber ragam & DB & JK & KT & $\mathrm{F}_{\text {hit }}$ & $\mathrm{F}_{0,05}$ \\
\hline Ulangan $(\mathrm{r})$ & 1 & $\left(\sum \mathrm{X}_{\mathrm{i} \cdot}{ }^{2} / \mathrm{t}\right)-\left(\mathrm{X} . .^{2} / \mathrm{rt}\right)$ & $\mathrm{JKr} / \mathrm{Dbr}$ & $\mathrm{KTr} / \mathrm{KTg}$ & 4.60 \\
Perlakuan $(\mathrm{t})$ & 14 & $\left(\sum \mathrm{X}_{\cdot \mathrm{j}}{ }^{2} / \mathrm{r}\right)-\left(\mathrm{X} . .^{2} / \mathrm{rt}\right)$ & $\mathrm{JKt} / \mathrm{Dbt}$ & $\mathrm{KTt} / \mathrm{KTg}$ & 2.48 \\
Galat $(\mathrm{g})$ & 14 & $\mathrm{JKT}-\mathrm{JKU}-\mathrm{JKP}$ & $\mathrm{JKg} / \mathrm{Dbg}$ & & \\
\hline Total & 29 & $\left(\sum \mathrm{X}_{\mathrm{ij}}{ }^{2}\right)-\left(\mathrm{X} .{ }^{2} / \mathrm{rt}\right)$ & - & - & -
\end{tabular}

Sumber : Warsa dan Cucu (1982)

Apabila dari analisis ragam terdapat keragaman yang nyata yaitu bila nilai Fhit $>$ Ftab analisis dilanjutkan dengan uji beda untuk setiap perlakuan berdasarkan Uji Jarak Berganda Duncan (Duncan's New Multiple Ranges Test) pada taraf nyata $5 \%$ dengan rumus:

$\operatorname{LSR}_{(\alpha . \text { dbg.p })}=\operatorname{SSR}_{(\alpha . \text { dbg.p })} \times \mathrm{S}_{\bar{x}}$

Nilai $\mathrm{S}_{\bar{x}}^{-}$dihitung berdasarkan rumus sebagai berikut :

Menguji efek sederhana apabila terjadi interaksi antara faktor $\mathrm{H}$ dengan $\mathrm{F}$, maka untuk membedakan antara $\mathrm{h}$ pada setiap taraf $\mathrm{f}$ atau sebaliknya digunakan rumus :

$$
\mathrm{S}_{\bar{x}}^{-}=\sqrt{\frac{\text { KTGalat }}{\mathrm{r}}}
$$

Menguji efek mandiri apabila tidak terjadi interaksi antara $\mathrm{h}$ dengan $\mathrm{f}$ yaitu :

a. Membedakan taraf $\mathrm{h}_{1}, \mathrm{~h}_{2}, \mathrm{~h}_{3}$ dan $\mathrm{h}_{4}$ digunakan rumus sebagai berikut :

$$
\mathrm{S} \bar{x}_{\mathrm{h}}=\sqrt{\frac{\text { KTGalat }}{r . f}}
$$

b. Membedakan taraf $\mathrm{f}_{1}, \mathrm{f}_{2}, \mathrm{f}_{3}$ dan $\mathrm{f}_{4}$, digunakan rumus sebagai berikut:

$$
\mathrm{S} \bar{x} \mathrm{f}=\sqrt{\frac{\text { KTGalat }}{r . h}}
$$

Keterangan : LSR= Least Significant Ranges; $\alpha=$ Taraf nyata; $\mathrm{dbg}=$ Darajat Bebas Galat; $\mathrm{p}=$ Jarak antar perlakuan; SSR= Studentized Significant Ranges; $\mathrm{R}=$ ulangan yang dilakukan; $\mathrm{KTG}=$ kuadrat tengah galat ; $\mathrm{S}_{\bar{x}}^{-}=$Galat baku rata-rata

\section{HASIL DAN PEMBAHASAN}

Hasil yang telah dicapai terbagi pada hasil respons pengamatan penunjang dan hasil respons pengamatan utama, dimana :

\section{Respons Penunjang}

Pengamatan penunjang dalam percobaan ini meliputi suhu selama percobaan di screen house dan di lapangan, kelembaban udara di screen house dan di lapangan, serangan hama dan penyakit pada saat perkecambahan dan pertumbuhan, gulma yang tumbuh dominan baik pada saat perkecambahan maupun pada saat pertumbuhan tanaman. Keadaan suhu udara ratarata selama percobaan suhu udara rata-rata di dalam screen house adalah $24^{\circ} \mathrm{C}$ dan kelembaban udara relatifnya adalah rata-rata $81,2 \%$. Sedangkan suhu udara rata-rata di lapangan lokasi Jatinangor adalah $23{ }^{\circ} \mathrm{C}$ dan kelembaban udara relatifnya adalah rata-rata 82,2 \% sedangkan di lapangan lokasi Cirebon $31^{\circ} \mathrm{C}$ dan kelembaban udara relatifnya adalah rata-rata 68,5 $\%$. Selama percobaan berlangsung ada beberapa gulma yang tumbuh di areal percobaan baik pada saat percobaan perkecambahan maupun pada percobaan pertumbuhan. Pada percobaan perkecambahan muncul gulma semanggi (Marsilea crenata), penanggulangannya dengan cara melakukan penyiangan setiap tiga hari sekali. Sedangkan selama percobaan pertumbuhan tanaman ditemukan beberapa macam gulma seperti teki-tekian (Cyperus difformis), semanggi (Marsilea crenata) dan jajagoan (Echinochloa crusgalli), penanggulangannya dilakukan dengan cara menyiang setiap satu sampai dengan dua minggu sekali tergantung dari tingkatan serangan gulma.

Gambar 1. Hama Belalang

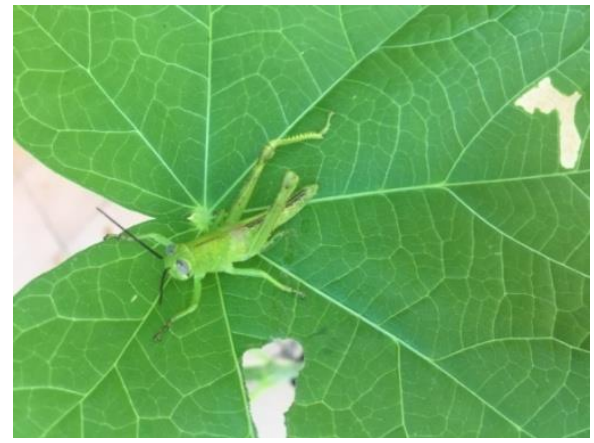


Pengamatan terhadap serangan hama dan penyakit pada saat percobaan perkecambahan, menunjukkan tidak ada gangguan serangan hama dan penyakit. Lain halnya dengan percobaan pertumbuhan tanaman, menunjukkan adanya serangan hama tetapi tidak ditemukan serangan penyakit. Jenis hama yang muncul yaitu belalang, ulat gerayak/tentara (Spodoptera litura), ulat jengkal (Hyposidra talaca) dan belalang (Valanga nigricornis).

Ulat gerayak/tentara (Spodoptera litura) menyerang daun dan batang tanaman padi semenjak tanaman padi muda sampai dengan tanaman padi dewasa dengan tingkat serangan relatif sedikit, pengendaliannya dilakukan dengan cara penyemprotan Sidamethrin 50 EC apabila hama sudah menyerang. Ulat jengkal (Hyposidra talaca) menyerang daun tanaman padi pada umur dewasa dengan tingkat serangan cukup tinggi, sehingga diperlukan pengendalian segera setelah serangan terjadi dengan menyemprotkan Sidamethrin 50 EC. Sedangkan belalang (Valanga nigricornis) menyerang hampir pada setiap stadia pertumbuhan, mulai dari pasca perkecambahan sampai memasuki fase generatif awal. Sama halnya dengan pengendalian hama ulat, hama belalang juga dikendalikan secara kimiawi dengan menggunakan Sidamethrin 50 EC.

\section{Respons Utama}

Respons utama atau pengamatan utama adalah pengamatan yang datanya digunakan untuk menjawab hipotesis, yang meliputi : kolonisasi mikoriza, biomassa akar dan FMA, dan tinggi tanaman.

\section{Kolonisasi Mikoriza}

Gambar 2. Akar Tanaman Terinfeksi Mikoriza

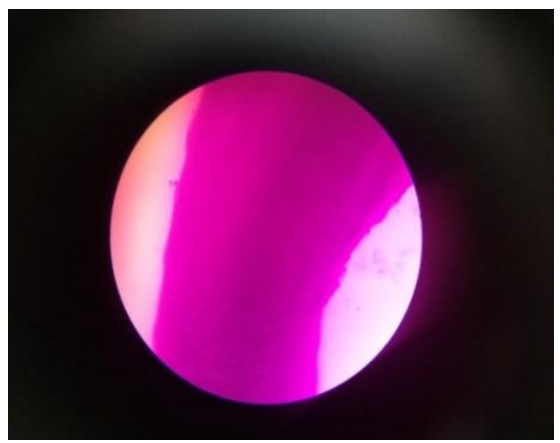

Gambar 2 menunjukan bahwa jaringan akar tanaman pagar yang terinfeksi Fungsi Mikoriza Arbuskular (FMA) mempunyai struktur percabangan hifa yang disebut arbuskular dan struktur khusus berbentuk oval yang disebut vesikel. Hasil perhitungan analisis sidik ragam mengenai kolonisasi mikoriza, tidak terjadi interaksi antara berbagai dosis konsorsium FMA dan kultivar jarak pagar terhadap kolonisasi mikoriza pada umur 21 HST dan 63 HST Di Dua Lokasi.

Tabel 2. Pengaruh Dosis Konsorsium FMA dan Kultivar Jarak Pagar terhadap Kolonisasi Mikoriza(\%) Pada Umur 21 HST dan 63 HST di dua Lokasi.

\begin{tabular}{|c|c|c|c|c|c|c|}
\hline \multirow[t]{2}{*}{ No. } & \multirow[t]{2}{*}{ Perlakuan } & \multicolumn{2}{|c|}{ Lokasi Cirebon } & \multicolumn{3}{|c|}{ Lokasi Jatinangor } \\
\hline & & $21 \mathrm{HST}$ & 63 HST & $21 \mathrm{HST}$ & & \\
\hline 1 & A & 1,55 a & $1,55 \quad a$ & 1,55 a & 2,61 & $\mathrm{a}$ \\
\hline 2 & B & 4,10 bc & 4,10 & $2,61 \quad a b$ & 4,87 & bc \\
\hline 3 & $\mathrm{C}$ & $2,61 \quad a b$ & $1,55 \mathrm{ab}$ & $3,66 \quad b c$ & 3,38 & $a b$ \\
\hline 4 & $\mathrm{D}$ & $10,16 \mathrm{~d}$ & $9,58 \mathrm{~d}$ & $10,15 \mathrm{~d}$ & 10,16 & $\mathrm{~d}$ \\
\hline 5 & $E$ & $9,98 \mathrm{~d}$ & $10,33 \mathrm{~d}$ & $10,15 \mathrm{~d}$ & 10,33 & $\mathrm{~d}$ \\
\hline 6 & $\mathrm{~F}$ & $9,52 \mathrm{~d}$ & $10,50 \mathrm{~d}$ & $8,92 \mathrm{~d}$ & 9,80 & $\mathrm{~d}$ \\
\hline 7 & G & $9,60 \quad d$ & $10,33 \mathrm{~d}$ & $10,50 \mathrm{~d}$ & 10,16 & $\mathrm{~d}$ \\
\hline 8 & $\mathrm{H}$ & $10,15 \mathrm{~d}$ & $10,33 \mathrm{~d}$ & $9,78 \quad d$ & 9,81 & $\mathrm{~d}$ \\
\hline 9 & I & $9,78 \mathrm{~d}$ & $10,15 \mathrm{~d}$ & $10,16 \mathrm{~d}$ & 10,33 & $\mathrm{~d}$ \\
\hline 10 & $\mathrm{~J}$ & 10,50 & 9,98 & $10,50 \mathrm{~d}$ & 9,98 & $\mathrm{~d}$ \\
\hline 11 & $\mathrm{~K}$ & $10,16 \mathrm{~d}$ & $10,15 \mathrm{~d}$ & $10,33 \mathrm{~d}$ & 9,75 & $\mathrm{~d}$ \\
\hline 12 & $\mathrm{~L}$ & $10,50 \quad d$ & $9,81 \quad d$ & $9,78 \quad \mathrm{~d}$ & 10,16 & $\mathrm{~d}$ \\
\hline 13 & $\mathrm{M}$ & $10,33 \mathrm{~d}$ & $9,96 \mathrm{~d}$ & $9,98 \mathrm{~d}$ & 10,50 & $\mathrm{~d}$ \\
\hline 14 & $\mathrm{~N}$ & $9,81 \quad \mathrm{~d}$ & $10,33 \mathrm{~d}$ & $10,50 \mathrm{~d}$ & 9,18 & $\mathrm{~d}$ \\
\hline 15 & 0 & $10,50 \quad \mathrm{~d}$ & 10,50 & $10,33 \mathrm{~d}$ & 10,50 & $\mathrm{~d}$ \\
\hline
\end{tabular}

Keterangan : Angka rata-rata yang diikuti huruf yang sama menunjukkan berbeda tidak nyata berdasarkan Uji Jarak Berganda Duncan pada taraf nyata $5 \%$. 
Perlakuan secara mandiri, dosis konsorsium FMA dan kultivar jarak pagar menunjukkan pengaruh yang nyata terhadap kolonisasi mikoriza. Perlakuan D, E, F, G, H, I, J, K, L, M dan O untuk semua periode pengamatan umur 21 HST dan 63 HST di dua lokasi menunjukan kolonisasi mikoriza yang lebih tinggi dan berbeda nyata dengan perlakuan A, B dan C. Perlakuan A, B, dan C menunjukkan nilai yang lebih rendah tingkat persentase kolonisasi mikorizanya karena perlakuan A, B, dan C merupakan kontrol (0 gram) Untuk lebih jelasnya pengaruh dosis konsorsium FMA dan kultivar jarak pagar terhadap kolonisasi mikoriza pada umur 21 HST dan 63 HST di dua lokasi dapat dilihat pada Tabel 2. Pemberian Fungi Mikoriza Arbuskular bentuk konsorsium pada semua kultivar tanaman jarak pagar, memberikan gambaran derajat infeksi FMA yang bervariasi pada akar tanaman jarak pagar. Fenomena terjadi perbedaan keefektifan antar isolat yang diberi, kemungkinan diduga adanya peran dari mikroorganisme lain selain FMA, misalnya adanya bakteri yang berinteraksi dengan FMA tersebut.
Beberapa hasil penelitian menunjukkan bahwa bakteri dapat membantu mikoriza dalam meningkatkan kolonisasi terhadap tanaman pinus strobes di pembibitan (Schelkle, 1996), tanaman wortel, dan Gmelina arborea Roxb. Sebelumnya (Smith, 2008) juga mengemukakan bahwa simbiosis antara mikoriza dengan tanaman juga dipengaruhi oleh adanya mikroorganisme lain yang ada di rizosfer terutama bakteri. Selanjutnya (Minerdi et al, 2002) menyimpulkan bahwa kolonisasi sel, kemampuan menyerap unsur hara dan air oleh FMA dan tanaman dipengaruhi oleh adanya bakteri yang ada di rizosfer tanaman tersebut.

\section{Biomassa Akar dan FMA}

Hasil perhitungan analisis sidik ragam mengenai kolonisasi mikoriza, tidak terjadi interaksi antara berbagai dosis konsorsium FMA dan kultivar jarak pagar terhadap biomassa akar dan FMA pada umur 21 HST dan 63 HST Di Dua Lokasi.

Tabel 3. Pengaruh dosisi konsorsing FMA dan Jarak Pagar terhadap Biomassa Akar dan FMA 9gr Pada Umur 21 HST dan 63 HST di dua lokasi.

\begin{tabular}{|c|c|c|c|c|c|c|}
\hline \multirow[t]{2}{*}{ No. } & \multirow[t]{2}{*}{ Perlakuan } & \multicolumn{3}{|c|}{ Lokasi Cirebon } & \multicolumn{2}{|c|}{ Lokasi Jatinangor } \\
\hline & & 211 & & 63 HST & $21 \mathrm{HST}$ & 63 HST \\
\hline 1 & $\mathrm{~A}$ & 0,57 & $\mathrm{a}$ & $3,44 \quad a$ & 0,23 a & $3,24 \quad \mathrm{a}$ \\
\hline 2 & B & 0,40 & $\mathrm{a}$ & $3,70 \mathrm{a}$ & $0,55 \mathrm{ab}$ & $3,82 \quad a$ \\
\hline 3 & $\mathrm{C}$ & 0,50 & $\mathrm{a}$ & $2,61 \mathrm{a}$ & $0,36 \mathrm{ab}$ & 3,03 a \\
\hline 4 & $\mathrm{D}$ & 0,39 & $\mathrm{a}$ & $3,92 \quad \mathrm{a}$ & 0,69 bc & $2,77 \quad a$ \\
\hline 5 & E & 0,57 & $\mathrm{a}$ & $2,96 \mathrm{a}$ & $0,62 \mathrm{ab}$ & $4,07 \quad \mathrm{a}$ \\
\hline 6 & $\mathrm{~F}$ & 0,58 & $\mathrm{a}$ & $4,83 \mathrm{a}$ & $0,38 \mathrm{ab}$ & 4,26 a \\
\hline 7 & G & 0,47 & $\mathrm{a}$ & $3,76 \mathrm{a}$ & $0,49 \mathrm{ab}$ & $6,90 \mathrm{c}$ \\
\hline 8 & $\mathrm{H}$ & 0,48 & $\mathrm{a}$ & $3,30 \quad a$ & 0,71 bc & $6,68 \mathrm{c}$ \\
\hline 9 & I & 0,43 & $\mathrm{a}$ & $3,10 \mathrm{a}$ & $0,49 \mathrm{ab}$ & $1,15 \mathrm{a}$ \\
\hline 10 & $\mathrm{~J}$ & 0,41 & $\mathrm{a}$ & 3,36 a & $0,42 \mathrm{~cd}$ & $1,59 \mathrm{a}$ \\
\hline 11 & $\mathrm{~K}$ & 0,54 & $\mathrm{a}$ & $4,80 \mathrm{a}$ & $0,89 \mathrm{ab}$ & 3,36 a \\
\hline 12 & $\mathrm{~L}$ & 0,40 & $\mathrm{a}$ & $3,56 \mathrm{a}$ & $0,48 \mathrm{ab}$ & $6,10 \mathrm{a}$ \\
\hline 13 & M & 0,40 & $\mathrm{a}$ & $3,24 \quad a$ & $0,51 \mathrm{ab}$ & 3,53 a \\
\hline 14 & $\mathrm{~N}$ & 0,55 & $\mathrm{a}$ & $3,74 \quad \mathrm{a}$ & $0,93 \mathrm{ab}$ & 3,81 a \\
\hline 15 & 0 & 0,44 & $\mathrm{a}$ & $4,86 \mathrm{a}$ & $0,38 \mathrm{~d}$ & $1,85 \mathrm{c}$ \\
\hline
\end{tabular}

Keterangan : Angka rata-rata yang diikuti huruf yang sama menunjukkan berbeda tidak nyata berdasarkan Uji Jarak Berganda Duncan pada taraf nyata 5\%. Perlakuan secara mandiri, dosis konsorsium FMA dan kultivar jarak pagar menunjukkan pengaruh yang nyata terhadap biomassa akar dan FMA. Pada Pengamatan 21 HST dan 63 HST di lokasi Cirebon menunjukkan hasil yang sama dan tidak berbeda nyata untuk semua perlakuan di kedua periode pengamatan. Umur tanaman 21 HST di lokasi Jatinangor perlakuan 0 menunjukkan hasil yang paling tinggi di bandingkan dengan semua perlakuan pengamatan terkecuali dengan perlakuan J yang menunjukkan sama tidak berbeda nyata. Pada perlakuan G, H, dan $\mathrm{O}$ menunjukkan hasil yang sama tidak berbeda nyata diantara ketiga perlakuan tersebut, tetapi ketiga perlakuan tersebut terbeda nyata dengan perlakuan $\mathrm{A}, \mathrm{B}, \mathrm{C}$, D, E, F, I, J, K, L, M, dan N. Untuk lebih jelasnya pengaruh dosis konsorsium FMA dan kultivar jarak pagar terhadap kolonisasi mikoriza pada 
umur 21 HST dan 63 HST di dua lokasi dapat dilihat pada Tabel 3 .

Perbedaan derajat infeksi akar tanaman jarak pagar (tanaman yang tidak dan diberikan konsorsium FMA), menyebabkan perbedaan biomassa akar dan FMA. Pemberian campuran konsorsium FMA (glomus sp., acaulospora sp., dan gigaspora sp.) sebanyak 10 gram dengan density jumlah spora sama menyebabkan biomassa akar dan FMA tertinggi dibandingkan dengan perlakuan lainnya. Struktur hifa di dalam akar tanaman dan tanah mampu meningkatkan luas areal untuk pertukaran hara dan air antara tanaman dan inang, sehingga mempunyai potensi yang besar untuk meningkatkan serapan dan translokasi hara terutama $\mathrm{P}$ ke tanaman jarak pagar. Hal ini sesuai dengan pendapat (Smith, 2008) bahwa panjang hifa ekternal dapat memcapai 7-10 m/g tanah.

\section{Tinggi Tanaman}

Gambar 3. Tanaman Jarak Pagar Di Pembibitan Di Dua Lokasi.

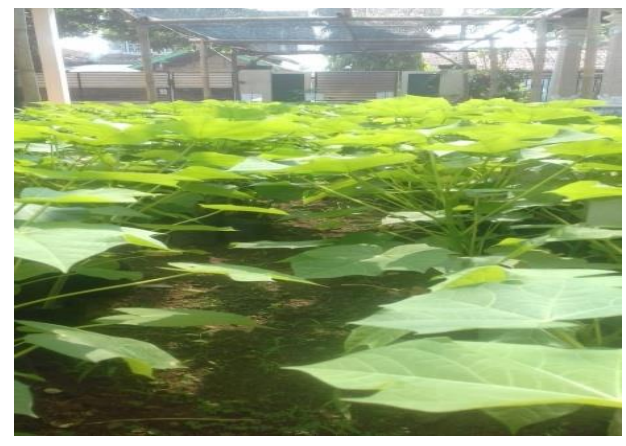

Hasil perhitungan analisis sidik ragam mengenai tinggi tanaman, tidak terjadi interaksi antara antara dosis konsorsium FMA dan berbagai kultivar jarak pagar terhadap tinggi tanaman pada umur 21 HST dan 63 HST di dua lokasi. Untuk lebih jelasnya pengaruh berbagai dosis konsorsium FMA dan berbagai kultivar jarak

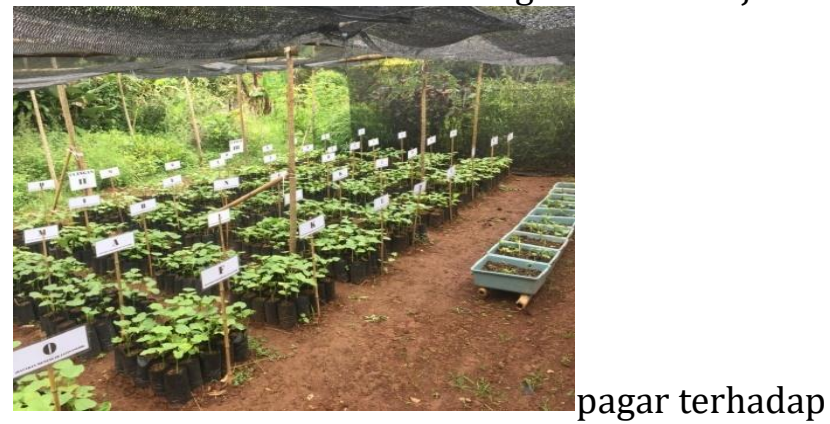

tinggi tanaman jarak pagar di pembibitan dapat dilihat pada Tabel 4.

Tabel 4. Pengaruh Dosis Konsorsing FMA dan Kultivar Jarak Pagar Terhadap Tinggi Tanaman (cm) pada Umur 21 HST dan 63 HST di dua lokasi.

\begin{tabular}{|c|c|c|c|c|c|c|}
\hline \multirow[t]{2}{*}{ No. } & \multirow[t]{2}{*}{ Perlakuan } & \multicolumn{2}{|c|}{ Lokasi Cirebon } & \multicolumn{3}{|c|}{ Lokasi Jatinangor } \\
\hline & & 21 HST & $63 \mathrm{HST}$ & 21 HST & 63 HST & \\
\hline 1 & A & $27,50 \quad a b$ & $47,08 \mathrm{ab}$ & $24,67 \mathrm{bc}$ & 38,38 & $\mathrm{a}$ \\
\hline 2 & $\mathrm{~B}$ & $31,00 \quad a b$ & $50,50 \mathrm{ab}$ & $24,50 \mathrm{bc}$ & 50,33 & $\mathrm{a}$ \\
\hline 3 & $\mathrm{C}$ & $29,67 \quad a b$ & $51,50 \mathrm{ab}$ & $24,58 \mathrm{bc}$ & 53,50 & $\mathrm{a}$ \\
\hline 4 & $\mathrm{D}$ & $31,33 \mathrm{ab}$ & $52,92 \mathrm{ab}$ & $27,75 \mathrm{e}$ & 50,75 & $\mathrm{a}$ \\
\hline 5 & $\mathrm{E}$ & $33,00 \quad a b$ & $46,00 \mathrm{ab}$ & $26,50 \mathrm{de}$ & 38,00 & $\mathrm{a}$ \\
\hline 6 & $\mathrm{~F}$ & 31,75 & $53,67 \mathrm{bc}$ & $22,25 \mathrm{ab}$ & 38,08 & $\mathrm{a}$ \\
\hline 7 & $G$ & $32,92 \quad a b$ & $48,83 a b$ & $26,00 \mathrm{~cd}$ & 50,25 & $\mathrm{a}$ \\
\hline 8 & $\mathrm{H}$ & $31,67 \quad a b$ & $56,83 \mathrm{c}$ & $26,33 \mathrm{de}$ & 49,00 & $\mathrm{a}$ \\
\hline 9 & I & 26,33 & $43,83 a b$ & $22,50 \mathrm{ab}$ & 41,83 & $\mathrm{a}$ \\
\hline 10 & $\mathrm{~J}$ & $31,17 \quad a b$ & $46,00 \mathrm{ab}$ & $28,08 \mathrm{e}$ & 46,33 & $\mathrm{a}$ \\
\hline 11 & $\mathrm{~K}$ & 29,00 & $51,00 \mathrm{ab}$ & 24,92 bc & 49,75 & $\mathrm{a}$ \\
\hline 12 & $\mathrm{~L}$ & 30,67 & $49,45 \mathrm{ab}$ & 20,25 a & 46,33 & $\mathrm{a}$ \\
\hline 13 & $\mathrm{M}$ & 37,58 & $47,83 \mathrm{ab}$ & $27,08 \mathrm{e}$ & 50,17 & $\mathrm{a}$ \\
\hline 14 & $\mathrm{~N}$ & 29,83 & $42,25 \mathrm{a}$ & $25,83 \mathrm{~cd}$ & 45,50 & $\mathrm{a}$ \\
\hline 15 & 0 & 29,33 & $43,00 \mathrm{ab}$ & $21,17 \mathrm{ab}$ & 40,58 & $\mathrm{a}$ \\
\hline
\end{tabular}


Keterangan : Angka rata-rata yang diikuti huruf yang sama menunjukkan berbeda tidak nyata berdasarkan Uji Jarak Berganda Duncan pada taraf nyata $5 \%$.

Hasil analisis data perlakuan konsentrasi asam sulfat berpengaruh nyata terhadap tinggi tanaman pada setiap periode pengamatan (21 HST, $63 \mathrm{HST}$ di Cirebon dan 21 HST di Jatinangor) kecuali pada umur 63 HST lokasi Jatinangor selanjutnya disajikan pada Tabel 4. Pada setiap periode pengamatan pada umur 21 HST lokasi Cirebon perlakuan $\mathrm{M}$ menunjukkan nilai tertinggi dan berbeda nyata dengan perlakuan lainnya, pada umur 63 HST lokasi Cirebon pada perlakuan $\mathrm{H}$ menunjukkan nilai tertinggi dan berbeda nyata dengan perlakuan lainnya, dan pada umur 21 HST lokasi Jatinangor pada perlakuan D, J, M menunjukkan nilai tertinggi dan berbeda nyata dengan perlakuan lainnya tetapi berbeda dengan umur 63 HST lokasi Jatinangor menunjukkan nilai yang tidak berbeda nyata dengan semua perlakuan.

Respon pertumbuhan bibit tanaman jarak pagar yang diinokulasi fungi mikoriza arbuskular (FMA) lebih tinggi dibandingkan dengan bibit tanpa FMA, Penelitian inimenunjukkan bahwa tanaman jarak pagar yang diberi isolat FMA memperlihatkan pertumbuhan yang lebih baik pada semua organ tumbuh yang diamati (akar, daun, dan batang) di kedua lokasi. FMA yang menginfeksi sistem perakaran tanaman inang akan memproduksi jalinan hifa eksternal secara intensif hingga menghasilkan panjang dan volume hifa eksternal yang optimal, akibatnya tanaman bermikoriza akan mampu meningkatkan kapasitasnya dalam menyerap unsur hara dan air (Sieverding, 1991).

\section{KESIMPULAN DAN SARAN}

\section{Kesimpulan}

Berdasarkan hasil penelitian dan pembahasan yang telah diuraikan pada sebelumnya, maka dapat ditarik kesimpulan keragaan pertumbuhan tanaman jarak pagar (jatropha curcass) di pembibitan akibat pemberian mikoriza di dua lokasi berbeda berdasarkan ketinggian tempat, bahwa dosis FMA konsorsium sebanyak 10 gram memberikan hasil yang terbaik untuk kolonisasi mikoriza, biomassa akar dan FMA, serta tinggi tanaman.

Rencana yang akan dilakukan oleh peneliti pada tahapan berikutya yaitu setelah didapat hasil terbaik dari dosis FMA konsorsium dari masingmasing kultivar selanjutnya menguji hasil tersebut dengan dikombinasikan pemberian konsentrasi sitokinin (BAP) di lapangan yang diharapkan dapat memperbanyak jumlah cabang tanaman yang dihasilkan karena sifat tanaman jarak tersebut merupakan tanaman berbunga terminal muncul bunga di ketiak daun setiap cabang, sehingga meningkatkan produksi jumlah biji yang dihasilkan dan meningkatkan rendemen minyak biofuel jarak pagar dengan karakteristik biodiesel yang memenuhi standar SNI.

\section{Saran}

Berdasarkan kesimpulan tersebut di atas maka dapat dikemukakan saran bahwa dari hasil yang dicapai, peneliti menyarankan untuk pemberian dosis FMA konsorsium sebanyak 0 gram tidak direkomendasikan karena tidak menunjukkan hasil yang tidak nyata untuk kolonisasi mikoriza maupun keragaan pertumbuhan tanaman jarak pagar di pembibitan yang dihasilkan oleh mikoriza tersebut.

\section{UCAPAN TERIMAKASIH}

Dalam kesempatan ini kami mengucapkan banyak terima kasih kepada : Rektor Universitas Winaya Mukti yang senantiasa memberikan dorongan dan motivasi kepada para dosen untuk melaksanakan tridharma perguruan tinggi; Ketua LPPM Universitas Winaya Mukti yang tanpa lelah memfasilitasi penelitian ini; Rekan-rekan kolega di Fakultas Pertanian Universitas Winaya Mukti yang turut membantu dalam pelaksanaan penelitian ini.

\section{DAFTAR PUSTAKA}

Cucu Suherman VZ. 2011. Peningkatan Pertumbuhan, Hasil Dan Rendemen Minyak Jarak Pagar (Jatropha curcas Linn) Melalui Aplikasi Fungi Mikoriza Arbuskula Dan Pupuk Fosfat Pada Inceptisol Jatinangor. Disertasi. Program Pascasarjana Unpad. Bandung.

Delvian. 2003. Keanekaragaman cendawan mikoriza arbuskula (CMA) di hutan pantai dan potensi pemanfaatannya. Studi kasus di hutan cagar alam Leuweung Sancang Kabupaten Garut, Jawa Barat. Disertasi. IPB.

Direktorat Budidaya Tanaman Tahunan. 2007. Pedoman Budidaya Tanaman Jarak Pagar. Melalui 
http://ditjenbun.deptan.go.id/tahunanbun /tahunan $>[12 / 6 / 2009]$.

Erliza Hambali, Ani Suryani, Dadang, Hariyadi, Hasim Hanafie, Iman Kartolaksono Reksowardojo, Mira Rivai, Muhamad Ihsanur, Prayoga Suryadarma, Soekisman Tjitrosemito, Tatang Hernas Soerawidjaja, Theresia Prawitasari, Tirto Prakoso, Wahyu Purnama. 2007. Jarak Pagar Tanaman Penghasil Biodiesel. Penebar Swadaya, Jakarta.

Gonzalo. B.E. And A. Miguel. 2006. Mycorrhizal An Eclogical Alternative for Sustainable Agriculture. Melalui http://www.micorhizal.html

Heller, J. 1996. Physic nut, Jatropha curcas L. Promoting the conservation and use of underutilized and neglected crop I. International Genetic Resouurces Institute, Rome. 66p.

Henning, R. 1996. Combating desertification: The Jatropha Project of Mali, West Africa. Aridland No.40, Fall/Winter 1996. The CCD, Part I: Africa and The Mediterranean. http://ag.arizona.edu/OALS/ALN/aln40/ja tropha.html [januari 2017].

Minerdi, D., V. Bianciotto, P. Biofante. 2002. Endosymbiotic bacteria in mycorrhizal fungi: from their morphology to geonomic sequences. Plant and Soil 244: 211-219.

Nuhamara, ST. 1994. Peranan Mikoriza Untuk Reklamasi Lahan Kritis. Program Pelatihan Biologi dan Bioteknologi Mikoriza.

Preston, S. 2007. Alternative Soil Amandements. NCAT Agriclture Specialist. National Sustainable Agricukture Information Service. ATTRA Publication. Melalui http://www.attra.ncat.org/attrapub/PDF/altsoil.pdf [8/3/2007].

Schelkle, M., and R.L. Peterson. 1996. Suppression of common root pathogens by helper bacteria and ectomycorrhizal fungi in vitro. Mycorrhiza. 6: 481-485.
Setiadi, Y. 2003. Arbuscular mycorizal inokulum production. Program dan Abstrak Seminar dan Pameran : Teknologi Produksi dan Pemanfaatan Inokulan Endo-Ektomikoriza untuk Pertanian, Perkebunan, dan Kehutanan. 16 September 2003. Bandung. Pp 10.

Smith, S.E. and D. Read. 2008. Mycorhiza Sybiosis. Academic Press. New York.

Suherman, C. 2008. Pertumbuhan Bibit Cengkeh (Eugenia aromatic 0.K) Kultivar Zanzibar Yang Diberi Fungi Mikoriza Arbuskula Dan Pupuk Majemuk NPK. Jurnal Agrivigor Vol. 8 No. 1.

Suherman, C., Anne Nuraini dan Harya Gusni. 2010. Pemanfaatan Cendawan Mikoriza Arbuskular Dan Zat Perangsang Tumbuh Akar Untuk Meningkatkan Pertumbuhan Bibit, Pertumbuhan, Hasil Serta Rendemen Minyak Nilam (Pogostemon cablin Benth). Prosiding Seminar Nasional Teknologi Tepat Guna Polinela, 5-6 April 2010. Politeknik Negeri Lampung. Lampung.

Sieverding, E. 1991.Vesicular arbuscular Mycorrhiza Management in Tropical Agrosystems. Deutsche Gessellschaft fur Technische Zusammenarbeit (GTZ), Eschborn, Germany.

Smith, S.E., D.J. Read 1997. Mycorrhizal Symbiosis. Second Edition. Academik Press. UK. 605 p.

Varma, A. 2008. Ecophysiology and application of arbuscular mycorrhizae fungi in arid soils. $\mathrm{P}$ 561-591. In A. Varma and B. Hock (ed) Mycorrhiza, structure, function, molecular biology and biotechnology. Springer. Verlag, Berlin.

Wahid, P. 2006. Jarak pagar dan lingkungan. Info Tek Jarak Pagar 1(5):18.

Warsa, T. dan Cucu S. A. 1982. Teknik Perancangan Percobaan Serial Pengenalan Dasar-dasar Statistika Terapan. Kelompok Staf Statistika Fakultas Pertanian. Universitas Padjadjaran, Bandung. 